DOI 10.18551/rjoas.2020-08.20

\title{
EFFECT OF SERVICE QUALITY AND CUSTOMER SATISFACTION OF WORD OF MOUTH IN PT. TELKOMSEL OF PALEMBANG CITY
}

\author{
Putra Andri Tryansyah* \\ Master's Study Program of Management, University of Sriwijaya, Palembang, Indonesia \\ Wahab Zakaria, Widiyanti Marlina, Saggaff Muchsin \\ Department of Management, Faculty of Economics, University of Sriwijaya, \\ Palembang, Indonesia \\ *E-mail: andritryansyahputra@gmail.com
}

\begin{abstract}
This study aims to determine whether the variables of service quality and customer satisfaction have an influence on word of mouth in GraPARI Telkomsel Palembang. The population in this study was all GraPARI Telkomsel Palembang customers, with a sample of 100 visitors who had used the GraPARI Telkomsel Palembang service before. This study uses multiple linear regression analysis techniques to determine the effect of service quality and customer satisfaction variables on word of mouth. The results of this study indicate that the service quality variable has a coefficient value of 0.416 and variable el customer satisfaction has a regression coefficient of 0.601 . This shows that both service quality and customer satisfaction variables have a significant effect on the word of mouth variable partially, with a greater influence on customer satisfaction variables on word of mouth compared to the service quality variable.
\end{abstract}

\section{KEY WORDS}

Service quality, customer satisfaction, word of mouth, Palembang.

One service industry that has developed quite rapidly in Indonesia in the last period is the telecommunications services industry with an average growth of $5.17 \%$ (Media Indonesia: 2019). According to the results of a review conducted by CNBC Indonesia in 2019, it was seen that Telkomsel's total revenue grew by $7.73 \%$ YoY (Year on Year), while its parent company (Telkom) grew $27.36 \%$, followed by its closest competitors XL and Indosat. It is undeniable that telecommunications services have become one of the basic needs in each region, as well as in the city of Palembang. Palembang with a population of 1,457,028 (Results of the 2010 Population Census: Statistics Indonesia) became a big market for Telkomsel in this city. Indonesia as one of the largest populations in Asia after China and India, has become an attractive and promising market for the development of the telecommunications industry.

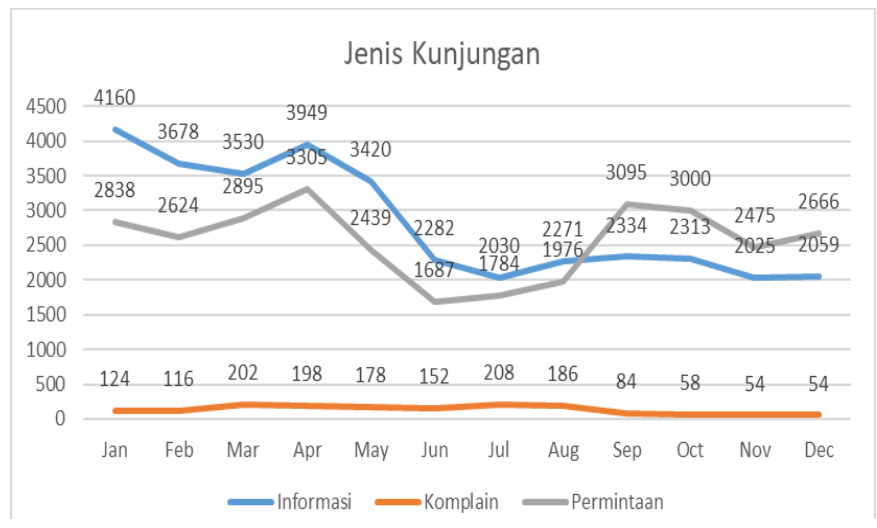

Figure 1 - Trend of Visit Types (Source: GraPARI Palembang 2019) 
The development of the telecommunications industry in Indonesia comes with several cellular operators, namely: Smartfren Telecom, Hutchison Charoen Pokphand Telecom (3), PT. Telkomsel, PT Indosat, Tbk, and PT XL Axiata, Tbk.

Figure 1 explains that the number of customer visits in GraPARI Telkomsel Palembang in the period January to December 2018 was 66,449 visits, with an average of 5,537 visits per month. Visits by customers are categorized into 3 types, namely information visits, complaints, and requests. Total visits by visit category were $34,051,1,614$, and 3,784 visits for information, complaints, and requests. It can be seen that the number of customers who came did not experience a high enough growth, as well as the level of complaints that only an average of 134 customers per month complained about customer dissatisfaction.

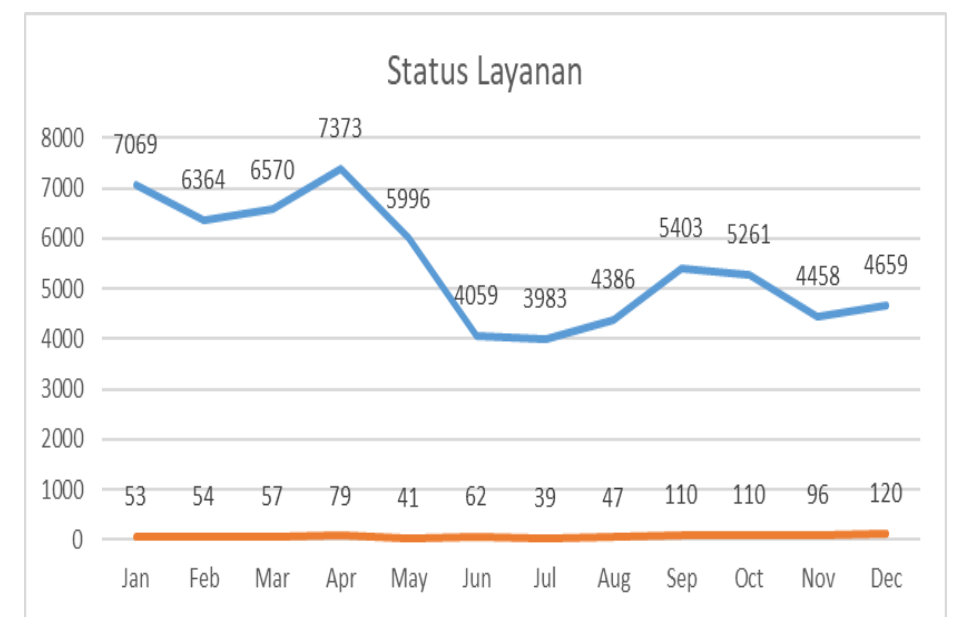

Figure 2 - Trend of Visit Types (Source: GraPARI Palembang 2019)

Figure 2 explains the GraPARI Telkomsel Palembang service for the period JanuaryDecember 2018 with 65,581 services with closed status, and 868 services with escalation status. In assessing customer satisfaction visiting GraPARI, PT. Telkomsel has surveyed customer satisfaction (Customer Experience Survey / CES) through the medium of SMS (Short Message Service). Where customers who come and have been served will get an SMS question about the satisfaction of the results of the service they have received.

Kartika and Shihab (2019) conducted a study with the findings showing that e-service quality, customer satisfaction and trust are the drivers of positive e-WOM. Wahyuni and Ekawati (2018) show that service quality and customer satisfaction have a positive and significant effect on word of mouth, this result confirms that good service quality can increase customer satisfaction with a service so that satisfied consumers will influence other consumers through word of mouth. Rambe, Maksum, and Jasmin (2017) found that service quality variables had a positive and significant effect on repeat purchases, customer satisfaction and word of mouth, and customer satisfaction variables had a positive and significant effect on repeat purchases and word of mouth. Perdana and Soesanto (2015) show that service quality and perceived value have a positive effect on Word of Mouth using customer satisfaction as a mediator or not, whereas service quality has the greatest impact on customer satisfaction followed by customer satisfaction by word of mouth, and the value that is perceived customer satisfaction.

Service quality is one of the key factors for company success and cannot be denied in today's business world because there is nothing more important for a company except placing customer satisfaction issues through service as one of its business commitments (Tjiptono, 2014). Later, business practitioners are demanded to do more, because the competitive climate is getting tougher and more competitive. With a focus on word of mouth described by Servonitz (2012), this is done by improving the quality of service following customer expectations. Word of mouth can be maximized by the concept of service quality by Parasuraman and Malhotra (2005) and also customer satisfaction by Kotler (2017). On 
this basis researchers are interested in researching "The Effect of Service Quality and Customer Satisfaction on the Word of Mouth of PT Telkomsel in Palembang City".

\section{THEORETICAL REVIEW}

According to Tjiptono and Chandra (2011), the concept of quality is considered as a measure of the perfection of a product or service consisting of design quality and conformance quality. Service is a very important factor, especially for companies engaged in services. The quality of service itself can be interpreted as a measure of how well the level of service provided can match customer expectations. If the service received or perceived exceeds customer expectations, the service quality is perceived as the ideal quality. Conversely, if the service received is lower than expected, the quality of service is perceived as poor quality. Two main factors affect service quality, namely expected service and perceived service or service quality expected and service quality received or felt (Tjiptono, 2011).

According to Parasuraman, Zeithaml, and Berry in Tjiptono (2011), five dimensions are used as guidelines by customers in assessing service quality, namely:

- Tangible (Tangible). Appearance facility physical, equipment, and personnel;

- Empathy (Empathy). Requirements for caring, giving personal attention to customers;

- Reliability (Reliability). The ability to carry out the services that were promised with proper and reliable;

- Responsiveness (Responsiveness). Willingness to help customers and provide services with quick or responsive;

- Confidence (Assurance). Employee's knowledge and courtesy and their ability to generate trust and confidence.

According to Kotler (2005), consumer satisfaction is the extent to which the level of the product is perceived according to the expectations of the buyer, a situation where the expectations of consumers of a product are following the reality received by consumers. Customer satisfaction will be achieved if expectations match the expectations received. Fornell et al. (1996) stated that customer satisfaction is high if the perceived value exceeds customer expectations. The more quality the products and services provided, the higher the satisfaction felt by the customer. When customer satisfaction is higher, it can lead to profits for the business entity. Vice versa, if without satisfaction, then it can result in customers moving to other products (Kotler \& Armstrong, 1996).

The existence of customer satisfaction will provide several benefits, among others (Tjiptono, 2006):

- The relationship between the company and its customers becomes harmonious;

- Provides a good basis for repeat purchases;

- Can encourage the creation of customer loyalty;

- Forming a recommendation from mouth to mouth that is profitable for the company;

- The company's reputation is good in the eyes of customers;

- Earnings were obtained be increased.

According to Tjiptono (1997), satisfaction or dissatisfaction of customers is the response of customers to evaluate the mismatch (disconfirmation) are perceived between the expectations of the previous and the performance of the actual product that is perceived that the competition which is getting tight these, increasingly many companies are involved in fulfilling the needs and desires of consumers.

Word of mouth communication (WOM) is a communication process in the form of giving recommendations both individually and in groups of a product or service that aims to provide information personally (Kotler \& Keller, 2012). Companies can encourage and facilitate word of mouth conversations by first ensuring that the products or brands of the company are indeed unique and innovative to create positive word of mouth communication. According to WOMMA (Word of Mouth Marketing Association) is an activity in which consumers provide information about a brand or product to other consumers. 
Consumers will prefer to buy the same brand that their friends buy. The credibility of the media is getting lower nowadays consumers are getting smarter not to directly believe in an ad that is read or viewed on social media. One reason, because there are too many ads and all talk about the same thing. According to Sumarni (2008), Kumala (2012) explains if customers are satisfied with the course they will promote word of mouth.

Word of mouth communication can create a negative image that can go against a brand. For this reason, marketers can take advantage of the steps above to counterattack negative word of mouth. But the most important thing is still superior service because that's where it all starts. S services superior is the most effective measures in the fight against the word of mouth that is negative.

Several studies (Anderson \& Sullivan, 1993; Bansal \& Taylor, 1999; Cronin \& Taylor, 2000) suggest a relationship between service quality and WOM behavior in the form of customer behavior to return to use services and customer recommendations to others to use these services. The better the quality of services provided by a company will be able to shape consumer behavior to create a WOM that benefits the company. But if the quality of services provided does not meet consumer expectations, WOM will not be created or even consumers will do WOM negative.

Consumer satisfaction is important for service providers, because consumers will disseminate their satisfaction to potential customers, so that it will enhance the reputation of the company and will create WOM to colleagues and their families. Brown et al. (2005) states that when a marketer can offer the maximum level of satisfaction to consumers, consumers will tend to do positive word of mouth. Also, he stated that there is a positive influence between customer satisfaction and word of mouth.

Various ways in service quality and customer satisfaction by Telkomsel in the city of Palembang in word of mouth are expected to get a positive image of consumers or customers. Consumer ratings of products, what is meant is getting good ratings from consumers. The assessment of consumers is very important, because it can be known whether the service quality and Telkomsel customer satisfaction in the city of Palembang has been received or embedded in the hearts of consumers.

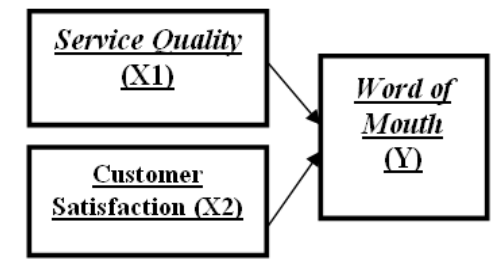

Figure 3 - Conceptual Framework

\section{METHODS OF RESEARCH}

The study population was GraPARI Telkomsel Palembang visitors. Samples of 100 respondents who use GraPARI Telkomsel Palembang services. Furthermore, the technique of determining the sample using the Non Probability Sampling Technique:

- Dependent / Free Variable (X), which is service quality \& customer satisfaction;

- Independent / Bound Variable (Y), i.e. word of mouth.

\section{RESULTS AND DISCUSSION}

Based on the results of the equation regression liner there is the influence of positive service quality $(X 1)$ of 0416 and the satisfaction of customers (X 2) for 0601 against the word of mouth $(\mathrm{Y})$. So word of mouth is very much influenced by service quality and customer satisfaction.

$$
Y=a+b_{1} X_{1}+b_{2} X_{2}
$$

Word of Mouth $=-1,807+0,416$ ServiceQuality $+0,601$ Customer Satisfaction 
Table 1 - Result Coefficient (R) and the Coefficient Of Determination (R2)

\begin{tabular}{lllll}
\hline \multicolumn{2}{l}{ Model Summary } & & & \\
\hline Model & $\mathrm{R}$ & $\mathrm{R}$ Square & Adjusted R Square & Std. Error of the Estimate \\
\hline 1 &, 793 &, 629 &, 621 & 1,99716 \\
\hline
\end{tabular}

The results of the correlation coefficient test $(r)$ price and tagline on buying interest that is equal to 0.793 or $79.3 \%$. R Square is 0.629 or $62.9 \%$. This value is used to find out how service quality and customer satisfaction variables provide the information needed to explain word of mouth together at $62.1 \%$ while the remaining $37.9 \%$ is influenced by other factors.

Table 2 - Test Result T (Individual Parameter Significance Test)

\begin{tabular}{|c|c|c|c|c|c|}
\hline \multicolumn{6}{|l|}{ Coefficients $^{\mathrm{a}}$} \\
\hline \multirow{2}{*}{ Model } & \multicolumn{2}{|c|}{ Unstandardized Coefficients } & \multirow{3}{*}{$\begin{array}{l}\text { Standardized Coefficients } \\
\text { Beta }\end{array}$} & \multicolumn{2}{|c|}{ Sig. } \\
\hline & B & Std. Error & & & \\
\hline 1 & -1.807 & 1.767 & & -1.023 & .309 \\
\hline Service Quality & .416 & .136 & .334 & 3.062 & .003 \\
\hline Customer Satisfaction & .601 & .132 & .496 & 4.548 & .000 \\
\hline
\end{tabular}

Service quality $\left(X_{1}\right.$ ) shows that the significance for $X_{1}$ to $Y$ is $0.000<0.05$ and $t$ arithmetic $5,408>t$ table 1.984. It can be concluded $\mathrm{H}_{1}$ accepted and service quality (X1) has significant positive effect on word of mouth at GraPARI Telkomsel Palembang.

\section{DISCUSSION OF RESULTS}

Based on the results of the test significantly partial proved that the influence of service quality to the word of mouth with the results statistically by $t_{\text {count }} 3,062>t$ table 1,984 and the level of significant $0,003<0.05$. Then it can be concluded that $\mathrm{H}_{1}$ is accepted. It was concluded that in partial service influence positively and significantly on word of mouth. It that means more and better services that provide by GraPARI Telkomsel Palembang increase word of mouth that positively affect GraPARI Telkomsel in Palembang.

These results are in line with previous studies conducted by Kartika and Shihab (2019), Wahyuni and Ekawati (2018), Rambe, Maksum and Jasmin (2017), Perdana and Soesanto (2015), Monica, John \& Maria (2017), Butt, Shah \& Iqbal (2016), Moreira \& Silva (2016), Mousavi, Nosratabadi \& Saeidi (2015), and Aulia \& Sendjaja (2015) which stated that service quality has a positive and significant effect on word of mouth.

Based on the results of the test significantly partial proven that influence satisfaction of customers on word of mouth $d$ ith the results statistically by $t_{\text {count }} 4,548>t$ table 1,984 and the level of significant $0,000<0.05$. Then it can be concluded that $\mathrm{H}_{2}$ is received. It was concluded that in partial satisfaction of customer impact positively and significantly on word of mouth. It that means more and better satisfaction of customers that given by GraPARI with good can increase w ord of mouth in GraPARI Telkomsel Palembang.

Satisfaction of the customers have influence positively and significantly on word of mouth in line with the results of Kartika and Shihab (2019), Wahyu and Ekawati (2018), Rambe, infallible and Jasmin (2017), Prime and Susanto (2015), Chahal \& Dutta (2018), Santo (2018), Mardatilla, Kusyanti \& Aryadita (2017), Jung \& Seock (2017), Singh \& Crisafulli (2017), Sivadas \& Jind al (2016), Haghighikhah, Arabi \& Khadang (2016), Widodo \& Shihab (2016), Khana, Garg \& Rahman (2015), Suryani \& Hendryadi (2015) and Aulia \& Sendjaja (2015).

\section{CONCLUSION}

Based on the results of the research that has been described previously, it can dirarik conclusion as follows:

1. Service Quality Variable $\left(\mathrm{X}_{1)}\right.$ has a positive and significant effect on word of mouth in GraPARI Telkomsel Palembang; 
2. Customer Satisfaction Variable $\left(\mathrm{X}_{2)}\right.$ has a positive and significant effect on word of mouth in GraPARI Telkomsel Palembang.

\section{SUGGESTIONS}

GraPARI Telkomsel Palembang can provide more services to customers, prioritizing customer satisfaction, so that it can improve creating better word of mouth. GraPARI Telkomsel Palembang can give more attention to consumers regarding the services provided. Also provide media that helps the topic or message to work and get young people to discuss or transmit services to others.

It is hoped that further research can consider other variables that can affect word of mouth such as brand loyalty, perceived value, product quality and customer trust.

\section{REFERENCES}

1. Anderson, E.W. \& Sullivan, M.W. (1993). The Antecedents and Consequences of Customer Satisfaction for Firms. Marketing Science 12(2):125-143. http://dx.doi.org/10.1287/mksc.12.2.125.

2. Arikunto, S. 2006. Prosedur Penelitian. PT. Bina Aksara: Jakarta.

3. Aulia, S. \& Sendjaja, S. D. (2015). Pengaruh Service Quality Terhadap Kepuasan dan Word of Mouth di Perguruan Tinggi Swasta. Seminar Nasional Cendekiawan 2015.

4. Babin, B.J., Lee, Y.K., Kim, E.J. \& Griffin, M. 2005. Modeling Consumer Satisfaction and Word of Mouth: RestaurantPatronage in Korea. Journal of Service Marketing 19.pp. 133 $-139$.

5. Bansal, H.S., \& Taylor, S.F. (1999). The Service Provider Switching Model (SPSM). Journal of Service Research, 2(2), 200-218.doi:10.1177/109467059922007.

6. Birgelen, Marcel van, Ko de Ruyter dan Martin Wetzels (2000): "The Impact of Incomplete Information on the Use of Marketing Research Intelligence in International Service Settings", Journal of Service Research, Vol. 2, No. 4.

7. Boulding, W., Kalra, S. \& Zeithaml. V.A. 1993. A Dynamic Process Model of Service Quality: From Expectations to Behavior Intentions. Journal of Marketing Research. Vol. 30 (Feb). pp. 7-27.

8. Brown, T.J., Barry, T.E., Dacin, P.A. \& Gunst, R. F. (2005). Spreading The Word: Investigating Antecedents of Consumers' Positive Word-of-Mouth Intentions And Behaviors In A Retailing Context. Journal of the Academy of Marketing Science, 33 (2), 123-138.

9. Fornell, C., Johnson, M.D., Anderson, E.W., Cha, J. \& Bryant, B.E. (1996). Growing the trust relationship [Electronic version]. Journal of Marketing, 60(4), 7-18. Retrieved [insert date], from Cornell University, School of Hospitality Administration site: http://scholarship.sha.cornell.edu/articles/431/.

10. Ghozali, I, 2008. Persamaan Struktural, Konsep dan Aplikasi dengan Program AMOS Ver.5.0. Semarang: BP UNDIP.

11. Kotler, P. 2005. Manajemen Pemasaran. Jilid 1 dan 2. Jakarta: PT Indeks Kelompok Gramedia.

12. Kumala, O.B. (2012). Pengaruh Word of Mouth Terhadap Minat Beli Konsumen Pada Tune Hotels Kuta-Bali. Skripsi. Universitas Indonesia.

13. Lien, C.H., Cao, Y. \& Zhou, X. (2016). Service Quality, Satisfaction, Stickiness, and Usage Intentions: An Exploratory Evaluation in the Context of WeChat Services. Computers in Human Behavior (2017).

14. Liu, W.K., Lee, Y.S. \& Hung, L.M. (2016). The Interrelationships among Service Quality, Customer Satisfaction, and Customer Loyalty: Examination of the Fast-Food Industry. Journal of Foodservice Business Research, DOI: 10.1080/15378020.2016.1201644.

15. Makanyeza, C. \& Mumiriki, D. (2016). Are All Customers Really the Same? Comparing Service Quality and Satisfaction between Residential and Business Telecommunications Customers. Acta Commercii 16(1), a348. http://dx.doi. org/10.4102/ac.v16i1.348. 
16. Mardatilla, R., Kusyanti, A. \& Aryadita, H. (2017). Pengaruh Kualitas Layanan.

17. Mousavi, S.A., Nosratabadi, S. \& Saeidi, M.R. (2015). Effects of Banking Services Quality on the Customer Word of Mouth Advertising. International Journal of Economics, Commerce and Management Vol. III, Issue 9, September 2015.

18. Mowen. (1995). Perilaku Konsumen. Pustaka Ilmu: Jakarta.

19. Musanto, T. 2004, Faktor-Faktor Kepuasan Pelanggan dan Loyalitas Pelanggan: Studi Kasus pada CV. Sarana Media Advertising Surabaya. Jurnal Manajemen \& Kewirausahaan Vol. 6, NO.2, September 2004: 123 - 136.

20. Optimasi, D., Irawan, B. \& Suroso, I. 2018. Peran Kualitas Layanan Dalam Membangun Kepuasan Dan Komunikasi Dari Mulut Ke Mulut Pasien Rawat Jalan Rsd. Dr. Soebandi Jember. Jurnal Bisnis dan Manajemen. Vol. 12, No. 2 Mei 2018. Hal. 191 - 203.

21. Pasya, M.R.A., Nugroho, B. A. \& Hartono, B. (2018). Service Quality On The Customer Satisfaction Restaurant At Waroeng Steak And Shake City Of Malang.

22. Perdana, M.R.P. \& Soesanto, H. 2015. Analisis Pengaruh Langsung Kualitas Pelayanan, Persepsi Nilai Pelanggan Terhadap Word Of Mouth Serta Pengaruh Tidak Langsung Dengan Kepuasan Pelanggan Sebagai Intervening (Studi Pada RS Marzuki Mahdi Bogor). Diponegoro Journal of Management. Volum 5, Nomor 1, Tahun 2015, Halaman 1-10. ISSN (Online): 2337-3792.

23. Polancik, G. (2009) Empirical Research Method Poster. Jakarta.

24. Quluk, K. (2018). Pengaruh Word Of Mouth Dan Harga Serta Kualitas Produk Galvalum Terhadap Kepuasan Pelanggan Pada Cv. Mitra Kontruksi Di Lumajang.

25. Ramamoorthy, R., Gunasekaran, A., Roy, M., Rai, B.K. \& Senthilkumar, S.A. (2016). Service Quality and Its Impact on Customers' Behavioural Intentions and Satisfaction: An Empirical Study of the Indian Life Insurance Sector. Total Quality Management \& Business Excellence, DOI: 10.1080/14783363.2016.1240611.

26. Rambe, N., Maksum, C. \& Jasin, M. 2017. Pengaruh Pelayanan, Citra Merek Dan Harga Terhadap Pembelian Ulang Melalui Kepuasan Pelanggan Dan Word Of Mouth. Ekobisman Vol 1 No 32017 P-ISSN: 2528-4304 E-ISSN: 2697-9302.

27. Ranaweera, C. \& Prabhu, J. (2003). "The influence of satisfaction, trust and switching barriers on customer retention in a continuous purchasing setting". International Journal of Service Industry Management. Vol. 14 Issue: 4, pp.374-395, https://doi.org/10.1108/09564230310489231.

28. Reingen, P.H. \& Walker, B.A. 2001. Cross-Unit Competition foe a Market Charter: The Enduring Influence of Structure, Journal of Marketing. Vol. 65, pp. 29-31.

29. Roy, S.K., Shekhar, V., Lassar, W.M. \& Chen, T. (2018). Customer Engagement Behaviors: The Role of Service Convenience, Fairness and Quality. Journal of Retailing and Consumer Services 44 (2018) 293-304. 